\title{
PERFORMANCE MANAGEMENT FROM THE BOTTOM UP
}

\author{
Drorit Gassner (맘it.gassner@mail.huji.ac.il)
}

Anat Gofen (anat.gofen@ mail.huji.ac.il)

Nadine Raaphorst (‥j.raaphorst@ fgga.leidenuniv.nl)

Accepted for publication in Public Management Review

To be cited as: Gassner, D., Gofen, A., \& Raaphorst, N. (Forthcoming). Performance management from the bottom up. Public Management Review.

\begin{abstract}
Current interest in middle managers' compliance with performance management (PM) reforms focuses on their downward roles. To explore their understudied upward roles, this analysis draws on police chiefs' voice directed to senior management regarding the Israeli PM system as documented since its first introduction in 1999, and as reported both by chiefs and senior managers $(\mathrm{N}=54)$. Unfolding four patterns of inconsistencies between PM systems' design and the operational, daily, course-of-work, close-to-the-field managers' upward roles allows us to move beyond criticism to constructive efforts, and provides new insights for reconciling the well-documented gap between policy intentions and outcomes in PM reforms.
\end{abstract}




\section{INTRODUCTION}

Performance management (PM) systems have been expected to improve public services by generating performance information (PI) that would serve managerial decision-making (Choi and Moynihan 2019; Dull 2009; Moynihan 2008; Moynihan and Kroll 2015; Van Dooren, Bouckaert, and Halligan 2016). Public managers are expected to comply with performance management principles by utilizing PI as a managerial tool, such as "to better allocate resources, make decisions about strategy, reengineer processes, motivate workers, and usher in a new era of accountability" (Moynihan 2009:592; see also Melkers and Willoughby 2005; Poister and Streib 1999). Following this expectation that introduction of a PM system will be followed by public managers' utilization of PI for decision-making, numerous studies have attempted to better understand the ways PM systems are used, for what purposes, and to what extent (e.g., Behn 2003; Hong, Kim, and Son 2019; Moynihan, Pandey, and Wright 2012; Nitzl, Sicilia, and Steccolini 2018), as well as what influences usage patterns (e.g., Moynihan and Pandey 2010).

Responses of managers to the introduction of PM systems have been mostly portrayed in terms of compliance, that is, utilizing PI for varied managerial functions, such as evaluation, control, motivating employees, budgeting, and learning (e.g., Ammons and Rivenbark 2008; Behn 2003; Dull 2009; Julnes and Holzer 2001; Moynihan et al. 2012; Pollitt 2006), or, in contrast, as under-using, misusing, or abusing PI (e.g., Bevan and Hood 2006; Teelken 2008). Focusing on compliance with the implementation of PM systems shifts attention to the downward roles of middle managers in performance-oriented reforms. In contrast, the upwards roles of middle management, that is, exercising voice efforts within which operational information and knowledge are synthesized, communicated, and articulated upwards to higher levels of management (Floyd and Wooldridge 1992), are understudied not 
only in the context of performance-oriented reforms, but also within the public sector in general (Chen, Berman, and Wang 2014; Currie 2000; Meynhardt and Diefenbach 2012).

Moreover, emphasizing communication between close-to-the-field and upper-level management in the organization, the upwards roles of middle managers echo insights on how to enhance positive contributions and inhibit negative consequences of PM systems, which stress the significance of consistent and repeated recommendation to involve users of the systems who know the needs and the requirements on the ground (Cuganesan et al. 2014; Hood 2012; Van Dooren 2011) and to facilitate communication between many PM systems' users, especially those whose interests in PI usage are diverse (e.g., Moynihan 2008; Van Dooren 2011).

To better understand the upwards roles of middle management in performance management reforms, this study explores why middle managers communicate with senior management regarding the PM system. Analysis draws on the Israeli police PM system, which, since its first introduction in 1999, has been re-designed three times, thus allowing a long-term, dynamic perspective. We focus on the upwards roles of police-station chiefs for three reasons. First, chiefs are middle managers, who serve as the linking tier between strategic and operational levels, while playing a key role in implementation of policies and programs (Currie and Procter 2005; Floyd and Wooldridge 1992; Hales 2006). Moreover, middle managers are considered not merely as policy implementers, but rather as strategic assets for organizational change (Balogun 2003; Gatenby et al. 2015), and as potential initiators of innovations, who attempt to contribute to policy formulation (Borins 2000; Chen et al. 2014; Currie 2000). Second, police chiefs occupy a lower-level middle management position at the operational core, like school principals, heads of social services bureaus, chiefs of fire stations, and directors of health care clinics, all of which occupy the sole highest position in frontline organizations, which holds an overall accountability to its outputs and 
outcomes (Gassner and Gofen 2018). Measuring performance in frontline organizations, which often serve as the basic measurement unit, aims to increase hierarchical accountability (Hupe and Hill 2007). Nevertheless, acting “as the connecting link between 'steering' and 'doing"' (Gassner and Gofen 2018:564), this tier of management does not passively comply with the demands of higher levels of management. Rather, they resist or look for ways to bend or break the rules in order to harmonize with the local population they serve, thus, similar to other street-level officials, they are often considered "policy makers" and not merely "policy takers" (Authors). Third, chiefs not only occupy a unique middle management position that allows them to provide top management with access to operational knowledge (Floyd and Wooldridge 1992), they also serve as professional managers. Therefore, chiefs represent the well-established motto of 'Let managers manage,' which implies that because professionals are central to a better performance, it is recommended that "performance management should be in the hands of middle managers and front-line supervisors who best understand the situational requirements" (Van Dooren 2011:428). Indeed, chiefs play a key role in the implementation of PM systems not only because they are often the ones who are held accountable for performance results and regarded as "agents of hierarchical control" (Evans 2011:382), but also because the ways that they use the PM system have direct and immediate effects on local service provision. Moreover, performance results are often highly consequential for their careers (Bevan and Hood 2006; Pollitt and Bouckaert 2009).

This article begins with a review of how the current literature on performance management reforms refers to the responses of public managers to the introduction of PM systems. This review identifies that managers' responses are mostly portrayed as using, misusing, underusing, or abusing PI, which supports the suggestion that the current tendency is a downward focus, while relinquishing questions about responses that managers direct upwards to higher levels of management. Next, the significance of an upwards perspective for a more 
comprehensive understanding of influences of PM systems is discussed, drawing on recent insights and recommendations for improvement of performance management. After specifying the methods and describing the case, findings elaborate on how the implementation of a PM system meets the ground by presenting an analytical framework that specifies four patterns of upwards voice efforts. Emerging as attempts to reconcile formalities of PM systems with the operational, daily course of work, the upward roles of close-to-the-field managers allow moving beyond well-known criticism and negative consequences that follow the implementation of the PM system, to constructive attempts exercised to convince decisionmakers to modify PM formalities so that it will better match the challenges experienced during on-the-ground provision of public services. The last section discusses implications both to research and to practice.

\section{PUBLIC MANAGERS' RESPONSE: FOCUS ON [NON]COMPLIANCE}

Performance management is commonly defined as: "a system that generates performance information through strategic planning and performance measurement routines and that connects this information to decision venues, where, ideally, the information influences a range of possible decisions" (Moynihan 2008:5). This definition emphasizes the expectation that performance management will generate PI that will be used as an instrument for managerial decision-making. This expectation is not straightforward because the use of PI "cannot be directly observed and, therefore, cannot be directly enforced or rewarded" (Moynihan et al. 2012:469) and because performance management reforms often encounter cynicism (Radin 2006) while challenging the status quo by inviting conflicts (Moynihan et al. 2012). Notably, in terms of organizational position, users of PM systems range from low-level employees to senior management, including politicians and top managers (e.g. Pollitt 2018), middle managers (e.g., Hvidman and Andersen 2013; Melkers and Willoughby 2005; Moynihan and Hawes 2012; 
Sandfort, Ong, and McKay 2019), first line managers (e.g. Butterfield, Edwards, and Woodall 2004), and, at times, frontline workers (Brodkin 2011); all are expected to comply with performance management principles.

Despite the difficulty in observing usage of PI, numerous studies have attempted to better understand the ways through which managers respond to the introduction of PM systems, and whether they use PI, for what purposes, and to what extent (e.g. Angiola and Bianchi 2015; Behn 2003; Kroll 2015; Kroll and Vogel 2013; Lewandowski 2018; Tantardini 2019). In accordance, managers have often been portrayed as either complying, or as not complying, with performance management principles. Specifically, accumulated evidence regarding PI usage is mixed: at times, managers report using PI for decision-making in general (Ammons and Rivenbark 2008; Pollitt 2006), as well as for particular purposes, such as for planning (Julnes and Holzer 2001; Dull 2009), budgeting (Poister and Streib 1999), improving coordination and communication between units within the organization (Melkers and Willoughby 2005) as well as sanctioning and rewarding (Bauwens, Audenaert, and Decramer 2018; Moynihan et al. 2012). At other times, though, managers demonstrate indifference and ignore PI, which reflects a response of underuse (Teelken 2008). An additional response to introduction of PM systems is abuse of PI, as reflected in the well-documented practice of 'induced gaming' (e.g. Bevan and Hood 2006; Kerpershoek, Groenleer, and de Bruijn 2016; Taylor 2020), which denotes "behavioral changes [that] occur to maximize reported performance at the expense of, or without any corresponding increases in, actual performance" (Cuganesan, Guthrie, and Vranic 2014:281).

The varied attempts to identify which factors affect the extent and modes of PI usage further reflect the downward focus on managers' response, and emphasize, for example, incentives as crucial for motivating managers to use PI (Moynihan 2009; Swiss 2005) as well as managers' personality, attitudes, and beliefs (Kroll 2013; Moynihan and Pandey 2010). Usage of PI by managers is also affected by the characteristics of the system, including performance 
management regimes (Sandfort, Ong, and McKay 2019), goal clarity (Boyne and Chen 2007; Hvidman and Andersen 2013; Moynihan et al. 2012; Kroll 2015) and the quality of data, as reflected in its relevance, errors, and information overload (Ammons and Rivenbark 2008; Johnsen 2005; Radin 2006). Multiple organizational factors are also positively associated with PI use, including resources devoted to collecting and evaluating data (Julnes and Holzer 2001), organizational culture (Calciolari, Prenestini, and Lega 2018), specifically innovative culture (Melkers and Willoughby 2005; Moynihan et al. 2012), as well as internal political support for the PM system (Kroll 2015; Yang and Hsieh 2007). Other organizational factors inhibit usage of PM systems, such as central agencies' attempts to control the policy agenda (Moynihan and Ingraham 2004; Van Dooren 2011), external performance assessment (Döring, Downe, and Martin 2015), competing political priorities (Dull 2009), as well as workers' unions, which often try to avoid measuring workers to evaluate their performance (Julnes and Holzer 2001). This review demonstrates a downward perspective on PM systems' influence, while disregarding questions about managers' responses to the introduction of PM systems that are directed to higher levels of management.

\section{WHY AND HOW THE UPWARD ROLE OF MIDDLE MANAGEMENT MATTERS}

Middle management's upwards role in implementation, which entails synthesizing information and championing alternatives (Floyd and Wooldridge 1992), is understudied in the context of the public sector in general (Chen et al. 2014; Currie 2000; Meynhardt and Diefenbach 2012), despite its key position to contribute to organizational strategy and change (Balogun 2003; Gatenby et al. 2015) by allowing senior managers to better understand the ways formal policy meets the ground (Floyd and Wooldridge 1992). In a similar manner, the rich performance literature focuses on the downward responses of middle managers as regards implementing PM systems, while overlooking their upwards role. Specifically, the well-documented downward 
responses provide a detailed understanding of forms and antecedents of (non)compliance with PM systems, that is, whether, how, and what influences PM utilization. Studying upwards responses to introducing PM systems is expected to allow unfolding how PM design meets the ground, that is, to uncover the experiences of middle managers during implementation efforts and why they respond to PM as they do. Recent insights and recommendations on how to modify PM systems in order to enhance their positive contributions and inhibit their negative consequences emphasize the need to take into consideration the knowledge and perspective of implementers-for example, the consistent and repeated recommendation to involve in the design of the system users who are expected to use PI and users who know the needs and the requirements on the ground (Cuganesan et al. 2014; Hood 2012; Moynihan 2008; Van Dooren 2011). Moreover, indicating that a specific PM system "may work perfectly well under some conditions but fail under others" (Moynihan et al. 2011:i153), recent studies suggest that the social and political contexts within which PM systems are embedded significantly influence the ways through which users utilize the system. In the same manner, contextual particularities "determine the purpose, function, design, and effectiveness of each particular performance measurement and management system" (Gao 2015:87; see also, Hood 2012; Henman 2016; Moynihan 2008; Lewis 2015; Pollitt 2018; Van Dooren 2011). Consequently, it is crucial to understand the interaction of performance management reforms within the social and political context in which they are embedded, that is, the ways through which PM systems meet on-theground delivery of public services. Notably, a better understanding of upwards responses will potentially provide practical insights as well, and will contribute to a better alignment between the design of PM systems and the daily work of public service delivery. 


\section{RESEARCH APPROACH}

\section{Methods of data collection}

A qualitative design was employed in an attempt to uncover the chiefs' activities that were directed upwards to higher levels of management since the first introduction of the PM system in 1999 until its last modification in 2016. Data draws on semi-structured interviews with several complementary sources of information. Specifically, between 2013 and 2016, thirteen former and current senior managers, including three former police commissioners, as well as 41 former and current police station chiefs were interviewed. Interviews were conducted faceto-face and were audio-recorded and transcribed, or were recorded in detailed field notes, typed up during and shortly after each interview. Interviews lasted between one and two hours during which respondents were asked about their experiences with the PM system. Themes included criticism of measurement methods and inconsistencies between the PM system scores and actual results. Analysis also draws on official documents, as well as internal documents that describe the processes of the PM system's design during the years, including senior management protocols and minutes of meetings of the police stations chiefs' forum, which uncover the ongoing dialogue between the chiefs and the more senior police management, including the commissioner, sub-district commanders, district commanders, as well as professional management such as heads of professional units at the Traffic Department, or at the Investigations Department and professional management in the Research and Statistics Section, which is responsible for the design of the PM system.

\section{Analytical Procedure}

As with most qualitative analyses, the process was iterative and involved moving between data, codes, and emerging schemes (Hammersley and Atkinson 1995). Specifically, grounded theory (Charmaz 2000; Strauss and Corbin 1990) was employed to allow characteristics of managerial 
activities directed upwards to emerge from the data without imposing prior expectations. Following Strauss and Corbin (1990), the first step was “open coding," by which statements in the interview were named and compared with one another to decide which belonged together. Next, "axial coding" was applied in order to cluster discrete codes around specific "axes," i.e., points of intersection or conceptual commonalities (Strauss and Corbin 1990). Managerial upwards activities emerged as an upwards involvement comprising voice efforts, which aim at reconciling inconsistencies between PM system design and informants' daily course of work. Four distinguished motivations for upwards involvement emerged, which differ by two analytic dimensions: differentiating two sources of inconsistencies, that is, context-design mismatches and management-design mismatches; and differentiating defensive and productive efforts to differentiate voice that explained inconsistencies and voice that also suggested a solution. Importantly, analysis refers only to statements that describe interactions between chiefs and senior management. In accordance, chiefs' criticism that was not described as channeled to higher levels of management was not included in the analysis.

Establishing validity in qualitative research is known to be difficult, especially in relation to description, interpretation, and theory building (Maxwell 1996). Hence, in order to enhance the validity of our findings, and to address description and interpretation concerns, all interviews were recorded, transcribed, and analyzed using ATLAS.ti. Further, findings were triangulated with multiple sources of data. Specifically, each voice effort that was mentioned in an interview was later asked about at the end of additional interviews and sought in the documents. Moreover, not only were chiefs interviewed about their own managerial activities, senior managers and professional managers were asked about what followed PM system implementation, including responses of the chiefs, which further increases the validity of our findings. 


\section{UPWARD ROLES OF MIDDLE MANAGERS IN IMPLEMENTING PM SYSTEMS}

Responses of chiefs that were directed upwards, to upper-levels of management, were portrayed by formal documents, by the chiefs themselves, as well as by all senior managers interviewed as ongoing voice efforts, which echo the well-documented upwards role of middle management (Floyd and Wooldridge 1992). As mentioned above, only statements that described chiefs' actions directed upwards to upper level managers in the organization were included in the analysis. Notably, all interviewees, including senior managers, specified many voice efforts that the chiefs exercised to describe their experience with the operational implications of the PM system. Moreover, both the chiefs and senior management initiated these communication efforts. Specifically, chiefs sent letters and emails or requested meetings with higher-ups to voice their concerns. Chiefs also communicated their feedback through opportunities facilitated by top management and by professional management, including answering survey letters, participating in focus groups or in management meetings, as well as giving responses during meetings within which performance results were discussed, often known as "COMPSTAT meetings." Content-wise, chiefs' voice efforts were portrayed by all informants as translating and mediating street-level operational knowledge that chiefs voiced to professional management and to senior management, which further echoes the conventional definition of middle managers as those who give top management access to operational knowledge (Schmid, Floyd, and Wooldridge 2010).

In general, the content of these voice efforts indicates that, while extensively criticizing concrete aspects of the PM systems' formalities, chiefs do not undermine or question the underlying logic of performance measurement and management. In fact, the benefits of using the PM system were often mentioned. Moreover, chiefs' voices reflected an underlying belief that PM systems' design should and could serve their work of managing the direct delivery of 
policing to a local public, while criticizing concrete, specific aspects of the current PM system's formalities.

\section{Multi-faceted Dissonance between Design of PM Systems and On-the-ground Implementation}

Chiefs' upwards voice reflected a multi-faceted dissonance that followed the introduction of the PM system in 1999, and the implementation of its subsequent versions until 2016. Analysis identified two explanations for the dissonance, both ascribed to concrete clashes between specific aspects of the PM system's design and specific aspects of chiefs' daily course of work at the operational level. One source of dissonance referred to context-related inconsistencies, that is, clashes between the PM system's current design and some particularities of the local public served by the station, for example, score measurement that considers car theft as a performance indicator in a locality where almost no car thefts are committed. The additional source of dissonance referred to management-related inconsistencies, that is, clashes between the PM system's current design and some aspects of managing implementation at the operational level, for example, complicated calculation of a station score that does not allow the chief to know what is required in order to meet targets.

Alongside explaining to higher-ups in what ways current PM system design is inconsistent with delivering policing services on the ground, chiefs invested efforts in convincing relevant senior managers to modify the design of the PM system in order to adjust its formalities to better manage implementation on the operational level. Indeed, alongside the articulation of a specific mismatch problem, many of the voice efforts also articulated a concrete proposition on how to resolve the mismatch. Notably, each of the solutions mentioned specifies how to modify PM system formalities in order to reconcile the dissonance. Insisting that PM system design should be adjusted to the operational delivery of policing and not vice versa was explained by referring to modifications in the station's course of work in an attempt 
to achieve higher scores that were "made at the expense" of activities that they considered to be more effective and worthy in terms of improving the policing services they provide to the local population. To distinguish efforts that specify a solution from those which focus on the problem, the former are referred to as productive and the latter as defensive.

\section{Upwards' Voice: Four Patterns of Attempts to Reconcile On-the-ground Dissonance}

Four patterns of attempts for dissonance reconciliation emerged, differentiated by drawing on two identified analytical dimensions: the distinction between two sources of dissonance, namely context-related and managerial-related, and between defensive and productive voices. Differentiating between sources of dissonance allows a better understanding of whether an inconsistency reflects a specific, local, context-related aspect, and thus calls for more flexibility in PM system formalities. In contrast, managerial-related inconsistencies are more likely to be relevant to close-to-the-field managers regardless of the locality they serve, thus their calls for a more general change in PM system design. The distinction between defensive and productive voices allows differentiating between more negative responses, which may be related to negative responses to the PM system that were mentioned above, as opposed to constructive efforts that reflect attempts not only to avoid blame but also to suggest constructive solutions. Specifically, the four patterns are:

a) Justifying unmet performance target (defensive, design-context mismatch);

b) Clarifying dysfunctionality (defensive, design-management mismatch);

c) Asking for an ad-hoc, local exemption (productive, design-context mismatch);

d) Offering future design modifications (productive, design-management mismatch). 
Table 1. Four Patterns of Attempts at Dissonance Reconciliation

\begin{tabular}{l|l|l}
$\begin{array}{l}\text { Strategies } \\
\text { Trigger }\end{array}$ & Defensive & Productive \\
\hline $\begin{array}{l}\text { Design- } \\
\text { context } \\
\text { mismatch }\end{array}$ & $\begin{array}{l}\text { Justifying unmet performance targets } \\
\text { e.g., between objects, priorities, and way } \\
\text { of calculation to the contextual } \\
\text { characteristics of the clientele served; }\end{array}$ & $\begin{array}{l}\text { Asking for ad-hoc, local exemption } \\
\text { e.g., measured by different indicators; }\end{array}$ \\
\hline $\begin{array}{l}\text { Design- } \\
\text { management } \\
\text { mismatch }\end{array}$ & $\begin{array}{l}\text { Clarifying managerial dysfunctions } \\
\text { e.g., lack of priorities; outdated } \\
\text { information; not reflecting the actual } \\
\text { results; }\end{array}$ & $\begin{array}{l}\text { Offering design modifications } \\
\text { e.g., building a simulator; factor } \\
\text { determination; multi-year average; }\end{array}$
\end{tabular}

In the following sections, each of the four patterns is elaborated, including the ways it was articulated by interviewees.

Justifying unmet performance targets entails voice efforts which emphasize chiefs' difficulties with meeting performance targets due to inconsistencies between different aspects of the measurement design and particularities of the local public served by the station. One prominent and explicit issue was measuring all stations according to the same metric tree, which overlooked the unique contextual characteristics of each station. This mismatch was explicitly discussed by providing concrete examples of the inability to meet performance targets and respond to local needs, such as being measured by car theft rates in an area where car thefts are very rare. Although PM system design changed to allow some variance between measurement of stations, the inability to meet targets required by the system while responding to local needs continued, emerging as a repeated critique about the mismatch between the police goals as presented by the system and responding to local public needs. Justifying unmet targets to derive from the design-context mismatch was also presented through concrete examples that demonstrate distorting the station's scores. In this pattern of upwards voice effort, managers present problems of PM system design as justifications for not meeting performance targets as measured by the system. 
Table 2. Justifying unmet performance targets

\begin{tabular}{|c|c|}
\hline Mismatch & Testimonials \\
\hline $\begin{array}{l}\text { Measuring all } \\
\text { stations according to } \\
\text { the same metric tree }\end{array}$ & $\begin{array}{l}\text { "There was an agreement [channeled by the chiefs] that the }\left[2^{\text {nd }} \text { generation] }\right. \\
\text { does not reflect the uniqueness of the station.... [it] forces everyone to work } \\
\text { according to the same priorities, and measures everyone according to the } \\
\text { same set of criteria and unified weights... This is how the [ } 2^{\text {nd }} \text { generation] } \\
\text { diverts the station from addressing its real challenges." (FocusGroup2005) }\end{array}$ \\
\hline $\begin{array}{l}\text { Irrelevance } \\
\text { specific } \\
\text { measurement } \\
\text { objectives }\end{array}$ & $\begin{array}{l}\text { "There is no focus on crimes, which does bother the citizen ... there is } \\
\text { insufficient reference to localized crimes..." (Commissioner-Presentation } \\
2014) \text {; } \\
\text { "What do they want me to do with } 3 \text { car thefts per year? To move the station } \\
\text { to reduce it while I need to reduce the illegal weapons possession that } \\
\text { happens here in numerous quantities?" (Chief3) }\end{array}$ \\
\hline $\begin{array}{l}\text { Measurement } \\
\text { objects do not } \\
\text { recognize actual } \\
\text { achievements }\end{array}$ & $\begin{array}{l}\text { "I have a } 30 \% \text { reduction in property crimes, but I do not have any } \\
\text { indictments. We reduced the crime, because [the station] invested in patrols } \\
\text { for prevention, which is the best tactic in this territory... and my score is } \\
\text { zero, because I am measured by indictments or by arrests." (Chief } 28 \text { ) }\end{array}$ \\
\hline No priorities & $\begin{array}{l}\text { "The message [from the System] was... you need to improve in all the } \\
\text { parameters all of the time... everything is important, everything's urgent... } \\
\text { you don't know what to deal with" (Chief5); } \\
\text { "They [station chiefs who worked under him] repeatedly said that... as a } \\
\text { managerial perception, exact definitions are required. What exactly is } \\
\text { expected from them?" (DistrictCommander1) }\end{array}$ \\
\hline
\end{tabular}

Clarifying Managerial Dysfunctions entails voice efforts that explain and justify the difficulties of the chiefs in exercising common managerial routines and activities, which derive from current design of the PM system. One repeated example was lack of priorities, which was ascribed to long and cumbersome lists of indicators that the system tracked, without setting any priorities. Consequently, chiefs were unable to understand what was expected from them and where to concentrate their efforts. An additional critique was voiced with regard to the frequency of the data updates, which emphasized a managerial difficulty to work with outdated information. Aspects of the system design which caused disconnection between results on the ground and performance scores calculated by the system were reflected in an additional repeated critique of inconsistency between design and managerial functionality. One specific example referred to measuring outputs and not outcomes, which resulted in high scores for stations where crime was increasing and in low scores for stations where crime was decreasing. 
Similarly, critique of the measurement method emphasized that the decision to compare the current year to the former creates "injustice," especially when the former years showed a continued improvement. In a similar manner, those who exemplified major improvements over the years, yet not during the last year, were also presented by the system as "under-achievers." In this pattern of upwards voice effort, managers present problems of their PM system's design as clarifications for managerial dysfunctions.

Table 3. Clarifying Managerial Dysfunctions

\begin{tabular}{ll}
\hline Mismatch & Testimonials \\
\hline Lack of priorities & "The message was... you need to improve in all the parameters all of the \\
time... everything is important, everything's urgent... you didn't know \\
what to deal with" (Chief5); \\
"We [chiefs] did not know what the commissioner would focus on in the \\
discussion, and it was like a huge test" (Chief16); \\
"...created difficulty in understanding where the focus is." (Chief15)
\end{tabular}

Asking for ad-hoc, local exemption entails specific requests by station chiefs to exclude one's station from the way performance measurement is designed by the system, such as by requesting to change objectives of measurement and expected targets. Examples include the request to be measured not according to the objectives of the system, that is, arrests of burglars, but rather according to arrests of illegal residents, as well as changing a specific level of target 
performance for varied reasons, such as changes in the "crime maps" or unexpected workload at the station, which required diversion of resources and reduced the ability to meet the performance target. Requests also referred to allowing exceptions, for example, to change the demarcation of hot spots, where chiefs experienced inability to influence, or in the criterion of whom the station could allow to participate in an intervention program.

Although reflecting a productive approach, such efforts implied rather self-serving motivation that aims at reconciling the dissonance for the specific station through an ad-hoc, particular solution that requests excluding the specific station from the general rule by modifying the way that station is measured. Many informants mentioned that senior management did listen, with a flexibility limit, as such requests were occasionally criticized for being suspected by senior managers as looking for the easy solution.

Table 4. Asking for ad-hoc, local exemption

\begin{tabular}{|c|c|}
\hline Exemption & Testimonials \\
\hline $\begin{array}{l}\text { Asking to change objectives } \\
\text { and targets }\end{array}$ & $\begin{array}{l}\text { "Policing at its best, which prevents crime rather than catching } \\
\text { criminals." (Chief11) }\end{array}$ \\
\hline $\begin{array}{l}\text { Asking to change the } \\
\text { demarcation of hot spots }\end{array}$ & $\begin{array}{l}\text { "They changed my hot-spots definition. It doesn't make sense to } \\
\text { invest policing resources in spots where I have zero possibility to } \\
\text { influence." (Chief1) }\end{array}$ \\
\hline $\begin{array}{l}\text { Asking to change the } \\
\text { criterion of whom to allow to } \\
\text { participate in an } \\
\text { intervention program }\end{array}$ & $\begin{array}{l}\text { "The headquarters directed that boys and girls who were involved } \\
\text { in drugs offenses are not allowed to participate in a program [for } \\
\text { youth rehabilitation]. Here everyone is involved in drugs offences. } \\
\text { So, when the commissioner arrived at the station for a visit, I asked, } \\
\text { and he excluded us so that they will be able to participate." (Chief5) }\end{array}$ \\
\hline $\begin{array}{l}\text { Asking to change a specific } \\
\text { level of target performance } \\
\text { for varied reasons, such as } \\
\text { changes in the "crime maps" }\end{array}$ & $\begin{array}{l}\text { "The entire industrial area is equipped with cameras. Now we have } \\
\text { fewer criminals to catch. Therefore, we will not meet the } \\
\text { performance target of arrests... we asked to reduce it." (Chief7) }\end{array}$ \\
\hline
\end{tabular}

Offering future design modifications for the PM system entails voice efforts that do not end by presenting the problem. Rather, these efforts go one step further and offer specific and concrete alternatives as to how the PM system should be modified in order to allow the system to support and improve managerial routines; they emphasize a potential improvement of the 
system and its usage. Varied modifications were mentioned, such as significantly decreasing the number of performance indicators and drawing on multiple-year averages as a performance score rather than merely on the last year's achievements, and by not ignoring achievements of the station in previous years. Suggestions for design modifications also included focusing on outcomes and not only on outputs, and adding overload measures to calculate a score that better reflects the policing provided on-the-ground and creates a more accurate picture of the station's functioning. In a similar manner, it was suggested to program a simulator that will give specific guidance about activities to exercise in order to meet performance targets, which was mentioned in some of the letters, as well as in the focus groups. In many ways, the modifications that were offered suggested altering the design of the PM system to allow a tailor-made PM system for each station by permitting more flexibility to reflect each station's unique features. Additional recommendations referred to measurement distortions that derive from small measures of offences.

Table 5. Offering PM system future design modifications

\begin{tabular}{|c|c|}
\hline Suggested solutions & Testimonials \\
\hline $\begin{array}{l}\text { To decrease the number of } \\
\text { performance indicators in } \\
\text { order to set priorities }\end{array}$ & $\begin{array}{l}\text { "You [senior management] should be clear. What are the } \\
\text { priorities... [with no priorities] you will not know the way to go. It } \\
\text { is the Cheshire Cat from "Alice in Wonderland'." (Chief36) }\end{array}$ \\
\hline $\begin{array}{l}\text { To calculate performance } \\
\text { score based on multiple-year } \\
\text { averages rather than merely } \\
\text { on the last year's } \\
\text { achievements }\end{array}$ & $\begin{array}{l}\text { "...by "taking into consideration achievements of previous periods } \\
\text { and giving a score based on these achievements." } \\
\text { (FocusGroup2005) }\end{array}$ \\
\hline To consider outcomes & $\begin{array}{l}\text { "...to balance the system so that outcomes will also be taken into } \\
\text { consideration and not only outputs." (Chief36) }\end{array}$ \\
\hline To add overload measures & $\begin{array}{l}\text { "... in order to take into account a station's achievements in relation } \\
\text { to its overload" (Chief11), which will allow "a better analysis of } \\
\text { the station's functioning." (FocusGroup2005) }\end{array}$ \\
\hline $\begin{array}{l}\text { To program a simulator that } \\
\text { will give specific guidance as } \\
\text { to which activities to exercise } \\
\text { in order to meet performance } \\
\text { targets }\end{array}$ & $\begin{array}{l}\text { "It is worthwhile to develop a simulator that would answer the } \\
\text { question: For a certain indicator at the present time, how much } \\
\text { should be added or removed (files, indictments, and so on) ... in } \\
\text { order to comply with the performance target by the end of the year } \\
\ldots \text { the simulator would help to plan the activities and save precious }\end{array}$ \\
\hline
\end{tabular}




\begin{tabular}{ll}
\hline time devoted at present to manual calculations." \\
(FocusGroup2005)
\end{tabular}

While all four patterns aim at reconciling the dissonance, they vary from shirkingorientation (justifying unmet targets) to a problem solving-orientation (offering future design modifications for the PM system). Moreover, attempts that refer to context-related inconsistencies often reflected a narrow perspective that strives to reconcile one's local, personal dissonance through an ad-hoc, local exemption that asks to be excluded from the general measurement rules and modifies the way one's specific station is measured. In contrast, attempts to reconcile management-related inconsistencies reflect a broader perspective that calls to revise the design of the PM so that the common issue experienced by all stations will be resolved.

These four patterns of dissonance reconciliation attempts demonstrate the unique structural position chiefs occupy, which facilitates an inherently conflictual buffering role: on one hand, they are responsible for the design, execution, and assessment of service delivery that is expected to meet the needs of the local population they serve (Gassner and Gofen 2018), while on the other hand, they are forced to modify implementation actions in order to meet measurement objectives and performance targets. 


\section{CONCLUSIONS}

To allow a better understanding of performance management impacts, this study shifts the focus to the upward roles of middle management in the implementation of PM systems, by exploring why chiefs explicitly direct voice efforts to higher levels of management. Notably, current scholarship often explores PM systems within a model of action (introducing a PM system) and reaction (how users of a PM system respond). Exploring PM from an upwards perspective, this study further emphasizes recent understanding that PM systems are "definitely not 'fire and forget.' They require active maintenance and continuing reconsideration" (Pollitt 2018:172; see also Gerrish 2016; Hood 2012). Furthermore, uncovering that upwards responses of chiefs first and foremost aim to reconcile a dissonance that was triggered by introducing a PM system further demonstrates the traditional, well-established twofold role of middle managers of synthesizing information and championing alternatives (Floyd and Wooldridge 1992), which is understudied in the context of the public sector (Chen et al. 2014; Meynhardt and Diefenbach 2012).

Three contributions emerged from shifting the focus to an upwards outlook on the implementation of PM systems. First, accumulated and varied evidence consistently casts doubt on whether performance management reforms have the potential to meet their purpose to improve public services and outcomes (Gerrish 2016; Radin 2006; Van Dooren et al. 2010; Siverbo, Cäker, and Åkesson 2019). In accordance, many studies recommend what could be done to enhance positive implications and inhibit negative consequences of PM systems' implementation (Henman 2016; Hood 2012; Moynihan et al. 2011; Pollitt 2018; Van Dooren 2011), suggesting that "if done correctly" performance-based reforms "can act as a performance-enhancing drug" (Hood 2012:S85; see also Gao 2015). This suggestion is further strengthened as findings here indicate that middle managers do not reject PM in principle. Rather, by elaborating on current mismatches between the design and formalities of the PM 
system and the realities of service delivery, middle managers reflect an acknowledgement of the potential benefits of PM and a belief that its design not only could but also should serve service delivery management, therefore suggesting that PM can indeed be done "correctly." Specifically, by identifying distinguished efforts to clarify managerial functions and concrete suggestions for PM design modifications, this study further emphasizes the well-established adage to 'Let managers manage,' which calls to put PM in the hands of close-to-the-field managers (Van Dooren 2011). In practice, this type of mismatch suggests that rather than having only a top management perspective, the perspective and day-to-day work of close-tothe-field managers should guide PM design, which is expected to allow better and more frequent use of PI during management of service delivery.

Second, and related, frontline officials have often been portrayed to be in a position that enables them to protect frontline discretion from "the performance measurement system of the state" (Breit, Fossestøl, and Andreassen 2017:37). Similarly, research has shown that close-tothe-field managers identify more with their professional workers than with senior management in the organization (Evans 2011). Uncovering chiefs' explicit and straightforward efforts to convince decision makers to reconcile inconsistencies between the design of the PM system and their daily work unfolds a more nuanced picture. That is, middle managers who are closeto-the-field do not simply try to 'protect' discretion from performance measurement by resisting working with it. Rather, by voicing their concrete critique, and even more so when offering solutions to senior managers, they attempt to reconcile the inconsistencies they experience so that the PM system will "work on the ground." In addition, identifying their attempts to articulate current problems, and the consequent convincing of senior management of the need to modify PM design, further exemplifies the political role of frontline organizations to structure processes through which each individual voice is asserted (Brodkin 2013). 
Finally, the current downward focus on the dynamics of PM often portrays users of PM systems as expected to comply with performance management, thus as reactive to implementation of PM systems. Moreover, the negative responses of PM systems' users are well-documented (e.g., Bevan and Hood 2006; Kroll 2015; Taylor 2020). By shifting attention to the upwards roles of middle management, findings of this study suggest that users of PM systems may act proactively and may exercise constructive efforts as well. Indeed, both justifying unmet performance targets and asking for ad-hoc, local exemption represent efforts that aim to address inconsistencies between the design of a given PM system and contextual particularities of the population served. From a practical perspective, these two patterns of efforts provide insights into how to follow the well-documented recommendation to consider PM systems as "requiring tuning to local circumstances" (Pollitt 2018:172; see also Gerrish 2016; Hood 2012). Specifically, in order to decrease inherent discrepancies between the characteristics of the locality served and the performance targets pre-determined by the system, more degrees of freedom should be enabled in setting performance objects and priorities of performance measurement according to the locality served by the frontline organization.

One major limitation of our study is considering motivations and considerations for upwards responses and not the actual influence of these responses. Hence, to further explore performance management, future research could analyze the process of the evolvement of PM systems in additional policy sectors, as well as by employing longitudinal designs, such as long-term observations, or panel studies. Such studies could reveal how upwards involvement (or the absence of it) is related to actual changes in PM design in additional policy sectors. This future research will also contribute to the upwards influences of lower level implementers in public organizations, to which little scholarly attention has been given (see, as exceptional, Arnold 2015; Frisch-Aviram, Cohen and Beeri 2018; Authors for frontline workers and Chen et al. 2014; Meynhardt and Diefenbach 2012 for middle managers). 


\section{REFERENCES}

Ammons, D. N., and W. C. Rivenbark. 2008. "Factors Influencing the Use of Performance Data to Improve Municipal Services:Evidence from the North Carolina Benchmarking Project." Public Administration Review 68(2):304-318.

Arnold, G. 2015. "Street-level policy entrepreneurship." Public Management Review 17(3):307-327.

Balogun, J. 2003. "From blaming the middle to harnessing its potential:Creating change intermediaries.” British Journal of Management 14(1):69-83.

Behn, R. D. 2003. "Why Measure Performance? Different Purposes Require Different Measures." Public Administration Review 63(5):586-606.

Bevan, G., and C. Hood. 2006. "What's Measured Is What Matters:Targets and Gaming in the English Public Health Care System.” Public Administration 84 (3):517-538.

Borins, S. 2000. "Loose cannons and rule breakers, or enterprising leaders? Some evidence about innovative public managers." Public Administration Review 60(6):498-507.

Boyne, G. A., and A. A. Chen. 2007. "Performance Targets and Public Service Improvement." Journal of Public Administration Research and Theory 17(3):455-477.

Bratton, W., and P. Knobler. 1998. Turnaround:How America's Top Cop Reversed the Crime Epidemic. New York:Random House.

Breit, E., K. Fossestøl, and T.A. Andreassen. 2017. "From pure to hybrid professionalism in post-NPM activation reform:The institutional work of frontline managers." Journal of Professions and Organization 5(1):28-44.

Brodkin, E. Z. 2011. "Policy Work:Street-Level Organizations under New Managerialism." Journal of Public Administration Research and Theory 21(suppl 2):i253-i277.

Brodkin, E. Z. 2013. "Street-Level Organizations and the Welfare State." In Work and the Welfare State:Street-Level Organizations and Workfare Politics, edited by E.Z. Brodkin and G. Marston, 17-34. Washington, D.C.:Georgetown University Press.

Butterfield, R., C. Edwards, and J. Woodall. 2004. "The New Public Management and the UK Police Service:The Role of the Police Sergeant in the Implementation of Performance Management." Public Management Review 6(3):395-415. 
Calciolari, S., A. Prenestini, and F. Lega. 2018. "An Organizational Culture for All Seasons? How Cultural Type Dominance and Strength Influence Different Performance Goals." Public Management Review 20(9):1400-1422.

Charmaz, K. 2000. "Grounded theory:Objectivist and constructivist methods." In Handbook of qualitative research, 2nd ed. edited by N. K. Denzin and Y. S. Lincoln, 509-35. Thousand Oaks, CA:Sage.

Chen, C.A., E.M. Berman, and C.Y. Wang. 2017. "Middle managers' upward roles in the public sector." Administration \& Society 49(5):700-729.

Choi, I., and D. Moynihan. 2019. "How to foster collaborative performance management? Key factors in the US federal agencies." Public Management Review 21(10):1538-1559.

Cuganesan, S., J. Guthrie, and V. Vranic. 2014. "The Riskiness of Public Sector Performance Measurement:A Review and Research Agenda." Financial Accountability \& Management 30(3):279-302.

Currie, G. 2000. "The public manager in 2010:the role of middle managers in strategic change in the public sector." Public Money and Management 20(1):17-22.

Currie, G., and S. J. Procter. 2005. "The Antecedents of Middle Managers' Strategic Contribution:The Case of a Professional Bureaucracy." Journal of Management Studies 42(7):1325-1356.

Döring, H., J. Downe, and S. Martin. 2015. "Regulating Public Services:How Public Managers Respond to External Performance Assessment." Public Administration Review 75(6):867-877.

Dull, M. 2009. "Results-Model Reform Leadership:Questions of Credible Commitment." Journal of Public Administration Research and Theory 19(2):255-284.

Evans, T. 2011. "Professionals, Managers and Discretion:Critiquing Street-Level Bureaucracy." British Journal of Social Work 41(2):368-386.

Floyd, S. W., and B. Wooldridge. 1992. "Middle Management Involvement in Strategy and Its Association with Strategic Type:A Research Note.” Strategic Management Journal 13 (S1):153-167.

Floyd, S. W., and B. Wooldridge. 1994. "Dinosaurs or Dynamos? Recognizing Middle Management's Strategic Role." The Academy of Management Executive 8(4):47-57. 
Frisch-Aviram, N., N. Cohen, and I. Beeri. 2018. "Low-level bureaucrats, local government regimes and policy entrepreneurship. " Policy Sciences 51(1):39-57.

Gao, J. 2015. "Performance measurement and management in the public sector:some lessons from research evidence.” Public Administration and Development 35(2):86-96.

Gassner, D., and A. Gofen. 2018. "Street-level Management:A Clientele-Agent Perspective on Implementation." Journal of Public Administration Research and Theory 28(4):551568.

Gatenby, M., C. Rees, C. Truss, K. Alfes, and E. Soane. 2015. "Managing change, or changing managers? The role of middle managers in UK public service reform." Public Management Review 17(8):1124-1145.

Gerrish, E. 2016. "The Impact of Performance Management on Performance in Public Organizations:A Meta-Analysis.” Public Administration Review 76(1):48-66.

Hales, C. 2006. "Moving down the Line? The Shifting Boundary between Middle and FirstLine Management.” Journal of General Management 32(2):31-55.

Hammersley, M., and P. Atkinson. 1995. Ethnography:Principles in practice. London, UK:Routledge.

Henman, P. 2016. "Techniques and paradoxes in performing performance measurements: concluding reflections." Policy Studies 37(6):597-609.

Hong, S., Kim, S. H., and J. Son. 2019. "Bounded rationality, blame avoidance, and political accountability: how performance information influences management quality." Public Management Review, 1-24.

Hood, C. 2012. "Public Management by Numbers as a Performance-Enhancing Drug:Two Hypotheses.” Public Administration Review 72(s1):S85-S92.

Hupe, P., and M. Hill. 2007. "Street-Level Bureaucracy and Public Accountability.” Public Administration 85(2):279-299.

Hvidman, U., and S. C. Andersen. 2013. "The Impact of Performance Management in Public and Private Organizations." Journal of Public Administration Research and Theory 24(1):35-58. 
Johnsen, Å. 2005. "What Does 25 Years of Experience Tell Us about the State of Performance Measurement in Public Policy and Management?" Public Money and Management 25 (1):9-17.

Julnes, P.D.L., and M. Holzer. 2001. "Promoting the utilization of performance measures in public organizations:An empirical study of factors affecting adoption and implementation." Public Administration Review 61(6):693-708.

Kerpershoek, E., M. Groenleer, and H. de Bruijn. 2016. "Unintended Responses to Performance Management in Dutch Hospital Care:Bringing Together the Managerial and Professional Perspectives.” Public Management Review 18(3):417-436.

Kroll, A. 2013. "Explaining the Use of Performance Information by Public Managers: A Planned-Behavior Approach." The American Review of Public Administration 45(2):201-215.

Kroll, A. 2015. "Drivers of Performance Information Use: Systematic Literature Review and Directions for Future Research." Public Performance \& Management Review 38(3):459486.

Kroll, A. and D. Vogel. 2013. "The PSM-Leadership Fit: a Model of Performance Information Use." Public Administration 92(4):974-991.

Lewandowski, M. 2018. "Public managers' perception of performance information:the evidence from polish local governments." Public Management Review 21(7) 988-1010.

Lewis, M. J. 2015. “The politics and consequences of performance measurement.” Policy and Society 34(1):1-12.

Maxwell, J. A. 1996. Qualitative research design. Newbury Park, CA:Sage.

Melkers, J., and K. Willoughby. 2005. "Models of Performance-Measurement Use in Local Governments:Understanding Budgeting, Communication, and Lasting Effects." Public Administration Review 65(2):180-190.

Meynhardt, T., and F. E. Diefenbach. 2012. "What drives entrepreneurial orientation in the public sector? Evidence from Germany's federal labor agency." Journal of Public Administration Research and Theory 22(4):761-792.

Moynihan, D. P. 2008. The Dynamics of Performance Management:Constructing Information and Reform. Washington, D.C.:Georgetown University Press. 
Moynihan, D. P. 2009. “Through a Glass, Darkly:Understanding the Effects of Performance Regimes." Public Performance \& Management Review 32(4):592-603.

Moynihan, D. P., and P. W. Ingraham. 2004. "Integrative Leadership in the Public Sector:A Model of Performance-Information Use.” Administration \& Society 36(4):427-453.

Moynihan, D. P., and A. Kroll. 2015. "Performance Management Routines That Work? An Early Assessment of the GPRA Modernization Act." Public Administration Review 67(2):314-323.

Moynihan, D. P., and S. K. Pandey. 2010. "The Big Question for Performance Management:Why Do Managers Use Performance Information?” Journal of Public Administration Research and Theory 20(4):849-866.

Moynihan, D. P., S. Fernandez, S. Kim, K. M. LeRoux, S. J. Piotrowski, B. E. Wright, and K. Yang. 2011. "Performance regimes amidst governance complexity." Journal of Public Administration Research and Theory 21(suppl_1):i141-i155.

Moynihan, D. P., S. K. Pandey, and B. E. Wright. 2012. "Setting the Table:How Transformational Leadership Fosters Performance Information Use.” Journal of Public Administration Research and Theory 22(1):143-164.

Moynihan, D.P., and D.P. Hawes. 2012. "Responsiveness to reform values:The influence of the environment on performance information use." Public Administration Review 72(s1):S95-S105.

Nitzl, C., M. Sicilia, and I. Steccolini. 2018. "Exploring the links between different performance information uses, NPM cultural orientation, and organizational performance in the public sector.” Public Management Review 21(5):686-710.

Nõmm, K., and T. Randma-Liiv. 2012. "Performance Measurement and Performance Information in New Democracies:A Study of the Estonian Central Government." Public Management Review 14 (7):859-879.

Poister, T. H., and G. Streib. 1999. "Performance measurement in municipal government:Assessing the state of the practice." Public Administration Review 59(4):325-335.

Pollitt, C. 2006. "Performance Management in Practice:A Comparative Study of Executive Agencies." Journal of Public Administration Research and Theory 16(1):25-44. 
Pollitt, C. 2018. "Performance management 40 years on:a review. Some key decisions and consequences." Public Money \& Management 38(3):167-174.

Radin, B. 2006. Challenging the Performance Movement:Accountability, Complexity, and Democratic Values. Washington, D.C.:Georgetown University Press.

Sandfort, J., S.J. Ong, and C. McKay. 2019. "Performance Management Regimes in Practice: Examining the Local Agencies Implementing Temporary Assistance for Needy Families." The American Review of Public Administration 49(2):145-158.

Schmid, T., S. Floyd, and B. Wooldridge. 2010. "Putting the manager back into the picture:The value of a strategy process perspective." In Handbook of research on strategy process, edited by P. Mazzola and F. W. Kellermanns, 142-162. Northampton, MA:Edward Elgar Publishing.

Siverbo, S., M. Cäker, and J. Åkesson. 2019. “Conceptualizing dysfunctional consequences of performance measurement in the public sector." Public Management Review 1-23.

Strauss, A., and J. M. Corbin. 1990. Basics of qualitative research:Grounded theory procedures and techniques. London, UK:Sage.

Swiss, J. E. 2005. “A Framework for Assessing Incentives in Results-Based Management." Public Administration Review 65(5):592-602.

Tantardini, M. 2019. "Routine and nonroutine performance information:an assessment about substitution and complementarity." Public Management Review 21(5):755-774.

Teelken, C. 2008. "The Intricate Implementation of Performance Measurement Systems:Exploring Developments in Professional-Service Organizations in the Dutch Non-Profit Sector." International Review of Administrative Sciences 74(4):615-635.

Taylor, J. 2020. "Public Officials' Gaming of Performance Measures and Targets: The Nexus between Motivation and Opportunity." Public Performance \& Management Review 122.

Van Dooren, W. 2011. "Better performance management:Some single-and double-loop strategies." Public Performance \& Management Review 34(3):420-433.

Van Dooren, W., G. Bouckaert, and J. Halligan. 2016. Performance management in the public sector. $2^{\text {nd }}$ edition. NY:Routledge. 
Yang, K., and J. Y. Hsieh. 2007. "Managerial Effectiveness of Government Performance Measurement:Testing a Middle-Range Model." Public Administration Review 67(5):861-879. 